\title{
Strategi Pengembangan Potensi Sumber Daya Alam Hutan Mangrove Di Kawasan Kelurahan Ketapang Kecamatan Kademangan Kota Probolinggo
}

\section{Mangrove Forest Natural Resource Potential Development Strategy in Ketapang Village Area of Kademangan District of Probolinggo City}

\author{
Gilang Satria Prakosa ${ }^{1}$, Aji Sangjoko ${ }^{2}$, Eka Nanda Wijaya ${ }^{3}$, Arik Gunawan Setyono ${ }^{4}$ \\ ${ }^{1}$ (Teknik Mesin, Universitas Muhammadiyah Jember) Email: gilangsatriaprakosa.20211@ @mail.com \\ ${ }^{2}$ (Teknik Mesin, Universitas Muhammadiyah Jember) Email: ajisangjoko984@ gmail.com \\ ${ }^{3}$ (Teknik Mesin, Universitas Muhammadiyah Jember) Email: ekananda1123@ gmail.com \\ ${ }^{4}$ (Teknik Mesin, Universitas Muhammadiyah Jember) Email: arikg7810@gmail.com
}

\section{TUJUAN}

1. Untuk mengoptimalkan pemanfaatan sumber daya alam hutan mangrove di Kawasan Kelurahan Ketapang, Kecamatan Kademangan, Kota Probolinggo

2. Untuk mengetahui pengoptimalan pengembangan potensi sumber daya alam hutan mangrove sebagai faktor untuk peningkatan ekonomi lokal

\section{LANDASAN TEORI}

Mangrove merupakan tumbuhan yang mempunyai kemampuan khusus untuk beradaptasi dengan kondisi lingkungan ekstrim, seperti kondisi tanah yang tergenang, kadar garam yang tinggi bahkan pada kondisi tanah yang kurang stabil. Hutan mangrove adalah tipe hutan yang dapat tumbuh di daerah pasang surut (terutama di daerah terlindung, laguna, muara sungai) yang dapat tergenang pada saat surut dimana komunitas tumbuhan ini bertoleransi terhadap garam [1]. Mangrove dapat tumbuh dengan baik pada wilayah yang datar, dengan muara sungai yang memiliki arus deras yang dapat berfungsi sebagai penghalang erosi pantai. Mangrove memiliki manfaat, yakni dapat melindungi garis pantai dari abrasi,mengontrol banjir, penyerap bahan pencemar, serta mencegah intrusi air laut ke daratan [2]. Oleh sebab itu pentingnya zonasi kawasan konservasi pesisir perlu di lakukan untuk menentukan suatu wilayah dapat digunakan sebagai wilayah konservasi, zonasi ini juga akan memudahkan dalam pengawasan kawasan konservasi [3].

Pada umumnya mangrove juga mengandung bakteri selulosa yang mampu untuk mereduksi gula. Pada umumnya bakteri ini digunakan pada industri dan juga bioteknologi selain itu hal yang lebih penting adalah sebagai sumber nutrisi pada berkembangnya mangrove[4]. Untuk menjamin keberadaan dan kelestarian ekosistem mangrove yang terletak di wilayah pesisir, maka perlu dilakukan upaya konservasi ekoistem mangrove di wilayah pesisir. Salah satu upaya yang dapat dilakukan untuk mendukung konservasi ekosistem mangrove adalah pengelolaan obyek wisata alam diwilayah tersebut. Kegiatan pariwisata khususnya wisata alam bermanfaat untuk melindungi dan melestarikan ekosistem hutan mangrove yang merupakan daerah pemijahan, daerah asuhan, dan daerah mencari makan untuk berbagai macam biota [5].

Pengembangan ekowisata mangrove merupakan salah satu upaya pemanfaatan jasa lingkungan dari kawasan pesisir secara berkelanjutan. Ekowisata pada hutan mangrove dipandang dapat bersinergi dengan langkah konservasi ekosistem hutan secara nyata [6]. Dalam pengembangan objek wisata hutan 
mangrove terdapat halangan didalamnya diantaranya,kurangnya atraksi wisata pendukung, kurangnya sadar wisata dari masyarakat setempat, kurangnya kegiatan penanaman mangrove yang merupakan potensi objek wisata tersebut, sehingga perlu adanya pembinaan, pelatihan, penyuluhan terhadap masyarakat tentang pentingnya pengembangan potensi wisata yang ada [7]. Konversi hutan mangrove menjadi lahan pertambakan telah mengakibatkan kerusakan pesisir. Ekowisata merupakan salah satu pemanfatan hutan mangrove dari segi ekonomi untuk mencapai kesejahteraan. Selain itu, ekowisata ini secara langsung memiliki manfaat pelestarian alam [8].

Ekosistem mangrove memiliki keunikan yang dapat dimanfaatkan sebagai sumber daya alam yang memiliki potensi untuk dijadikan sebagai kawasan ekowisata. Seiring pesatnya perkembangan

kepariwisataan hutan mangrove dapat dijadikan ekowisata sebagai tujuan wisata mancanegara, saat ini muncul paradigma dan keinginan pasar wisata dengan konsep lingkungan hidup dan kembali ke alam (back to nature), yang juga dikenal sebagai wisata ekologis (ekowisata) dalam dunia pariwisata [9]. Desa yang memiliki komponen biofisik dapat mendukung untuk pengembangan kegiatan ekowisata mangrove. Salah satunya wilayah pesisir yang dikelilingi oleh mangrove tentunya rentan terhadap berbagai ancaman dan tekanan baik dari masyarakat dengan segala aktifitas pemanfaatan sumberdaya alam maupun ancaman dari alam itu sendiri [10]. Pengembangan ekowisata pesisir dan laut harus mempertimbangkan dua aspek, yaitu aspek tujuan wisata dan aspek pasar. Meskipun pengembangan ekowisata menganut konsep pengarusutamaan produk atau pasar, namun pengembangan produk wisata tetap menjamin kelestarian sumber daya alam dan budaya masyarakat pesisir dan laut. Pengembangan ekowisata pesisir dan laut lebih dekat kepada aspek pelestarian, karena di dalamnya sudah terkandung aspek keberlanjutan [11]. Hutan produksi berkelanjutan merupakan hutan yang dapat menghasilkan hasil yang bernilai ekonomis yang dapat digunakan untuk kebutuhan hidup saat ini dan di masa depan. Manfaat berbagai produk dan jasa dari hutan mangrove telah dirasakan oleh manusia, baik berupa kayu maupun produk non-kayu [12].

Pemanfaatan buah mangrove dapat menghasilkan baik menjadi makanan ataupun minuman olahan tersebut dapat dijual dan menambah pemasukan bagi warga di sektor ekonomi [13]. Salah satu spesies mangrove yang dapat diolah adalah Sonneratia sp. Sonneratia sp. dapat menghasilkan buah dalam jumlah besar. Buah pedada yang telah matang, buah pedada mengandung kadar air yang tinggi yaitu sekitar $85 \%$. Kadar air yang tinggi menyebabkan buah pedada mudah mengalami pembusukan, sehingga memerlukan penanganan cepat atau pengolahan untuk memperpanjang umur simpan sekaligus meningkatkan nilai tambah buah pedada. Salah satu bentuk olahan yang dapat dikenalkan ke masyarakat adalah sirup [14].

Dalam melakukan strategi pengembangan potensi sumber daya alam dapat menggunakan analisis SWOT agar dapat mengetahui daya potensi sumber daya alam hutan mangrove [15].

Luas hutan mangrove di Probolinggo pada tahun 2001 seluas 209,32 Ha. Sedangkan luas area mangrove pada tahun 2011 seluas 295,20 Ha. Hasil pendataan tersebut menunjukkan bahwa area mangrove selama kurun waktu sepuluh tahun 2001 sampai dengan tahun 2011 terlihat adanya peningkatan atau penambahan luas area hutan mangrove seluas 95,08 Ha yang terjadi di 36 desa. Adanya penambahan atau peningkatan luas hutan mangrove dan adanya penurunan atau berkurangnya luas hutan mangrove tersebut dapat diperhitungkan bahwa di Kota Probolinggo selama kurun waktu 11 tahun masih adanya peningkatan luas area hutan mangrove seluas 85,88 Ha.

Hutan mangrove yang terdapat di Kelurahan Ketapang tidak banyak yang memperhatikan, tak sedikit masyarakat yang menebangnya untuk dipergunakan sebagai kayu bakar, padahal jika dilihat dari fungsinya sangat bermanfaat bagi masyarakat banyak terutama para nelayan. Wilayah di sekitar Kelurahan Ketapang dicirikan sebagai hamparan ekosistem berupa sawah, sungai, tambak, kebun budidaya, dan lahan tak termanfaatkan atau lahan dengan tumbuhan yang dibiarkan tumbuh liar, sebagian besar ditumbuhi dengan Alang-alang yang merupakan spesies invasif yang dapat meniadakan keberadaan 
spesies lain, sehingga patut diwaspadai.

\section{METODE PENELIITIAN}

Kelurahan Ketapang memiliki potensi sumber daya alam yang melimpah berupa hutan mangrove. Lokasi potensi sumber daya alam tersebut terletak di Kelurahan Ketapang, Kecamatan Kademangan, Kota Probolinggo, Jawa Timur.

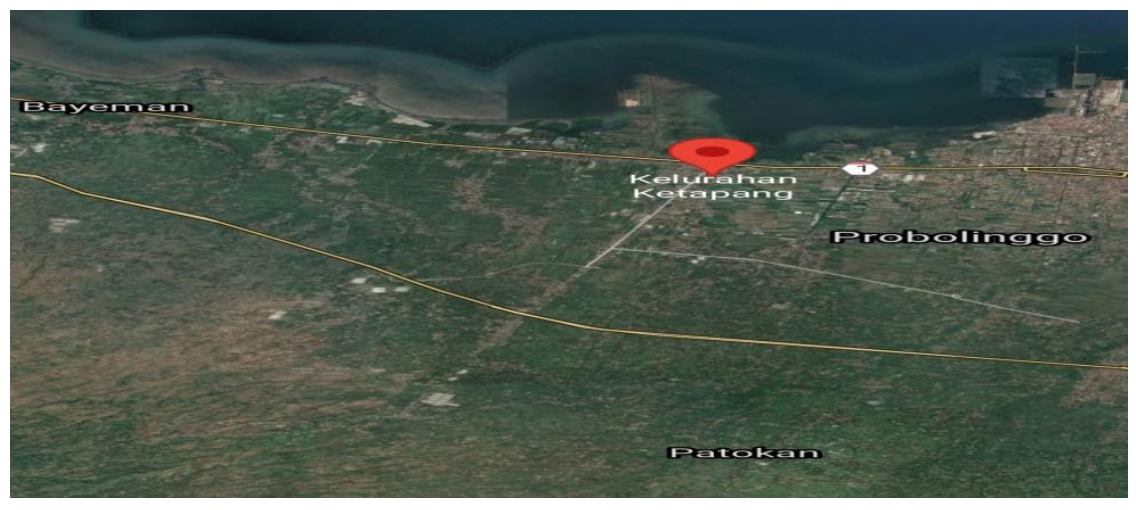

Gambar 1. Peta Wilayah Kelurahan Ketapang Kota Probolinggo

Penelitian ini menggunakan metode kualitatif melalui berbagai media literasi yang menunjukkan bahwa masih banyak potensi sumber daya alam yang salah satunya bisa dijadikan sebagai suatu produk yang memiliki nilai jual di pasaran dengan memanfaatkan sumber daya manusia sebagai pengelola potensi alam tersebut. Penelitian ini menguraikan secara umum langkah dalam mengembangkan potensi alam untuk sektor ekonomi di daerah setempat

Bahan pelatihan yaitu buah mangrove yang diperoleh dari kelompok tani mangrove Ketapang, Probolinggo. Kegiatan yang dilakukan meliputi penyuluhan, pelatihan dan pendampingan kelompok tani mangrove di kelurahan Ketapang, Probolinggo. 


\section{HASIL DAN PEMBAHASAN}

Setelah dilakukannya sosialisasi/penyuluhan terhadap buah mangrove terhadap kesehatan ratarata kelompok tani mangrove belum mengetahui bahwa buah mangrove dapat dijadikan suatu produk olahan yang memiliki nilai jual, yang mereka ketahui bahwa buah mangrove hanya digunakan sebagai bibit dari tanaman mangrove.

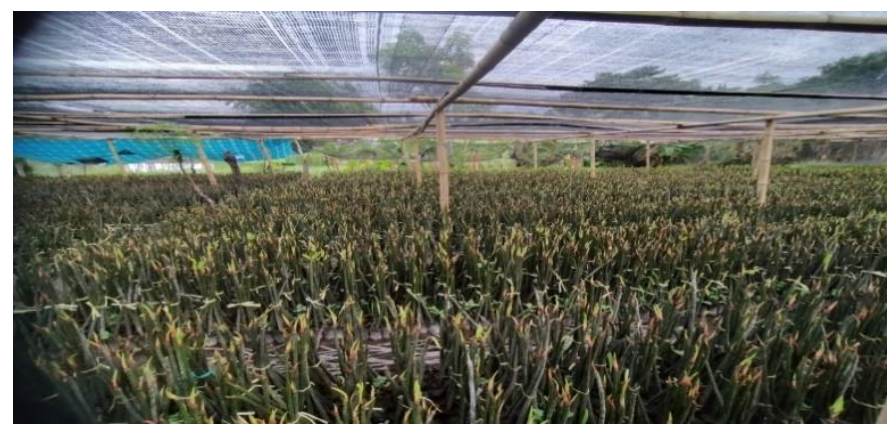

Gambar 2. Bibit tanaman mangrove

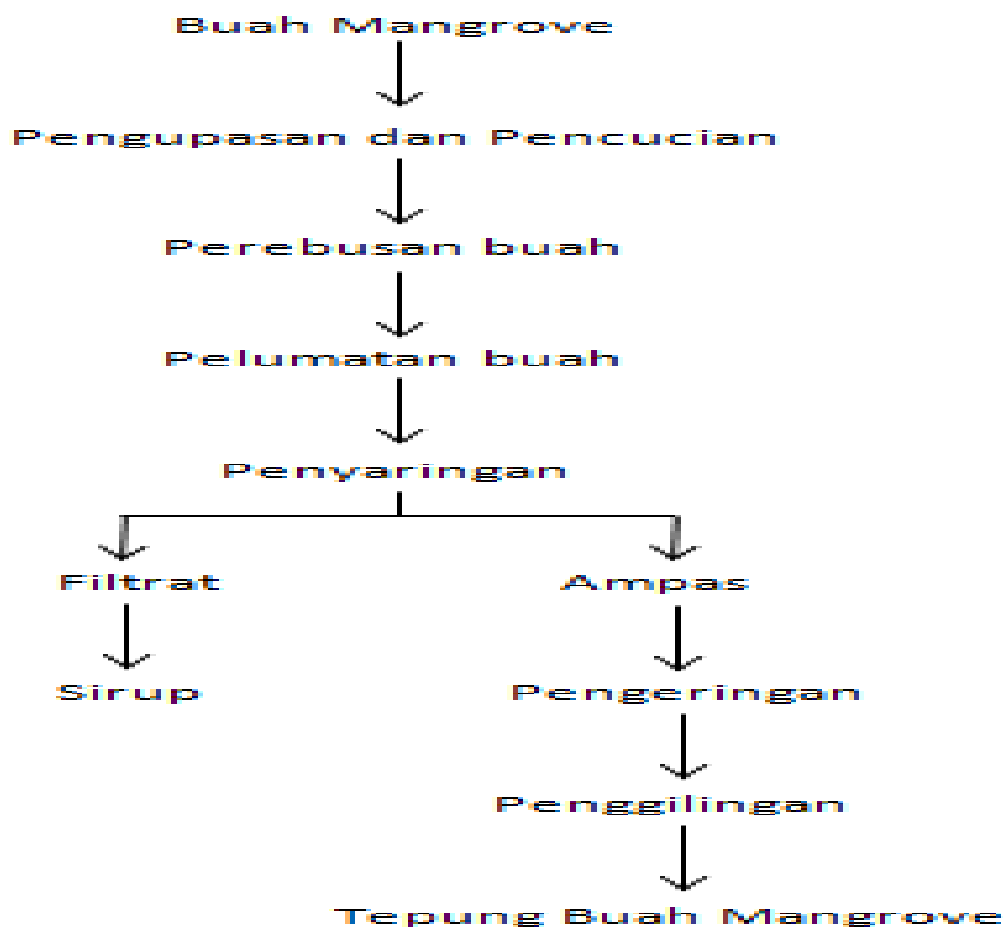

Gambar 3. Proses pengolahan buah mangrove menjadi suatu produk

Dapat dilihat dari gambar 3, langkah-langkah untuk mengolah buah mangrove untuk dijadikan bahan pangan atau minuman. Langkah yang pertama yakni buah mangrove di kupas lalu di cuci hingga bersih setelah melalui tahap pencucian buah direbus setelah direbus dalam beberapa jam buah tersebut dilumat hingga halus dan selanjutnya disaring untuk mendapatkan sari-sarinya. Setelah melalui tahap 
penyaringan dapat dihasilkan filtrate dan ampas, untuk ampas sendiri dilanjutkan pengeringan dan penggilingan hingga dihasilkan tepung buah mangrove. Sedangkan hasil filtrat dapat dijadikan sirup.

\section{KESIMPULAN}

Adanya kegiatan pelatihan tersebut dapat meningkatkan wawasan pengetahuan sehingga kelompok tani dapat mengembangkan produksi olahan buah mangrove, sekaligus merupakan suatu pembelajaran dan berbagi pengalaman serta ilmu pengetahuan secara langsung antara pelaksana dan kelompok tani mangrove. Adanya kegiatan pelatihan juga dapat memberikan wawasan terhadap warga ketapang untuk mengetahui potensi sumber daya alam hutan mangrove di ketapang dan dapat melestarikan hutan mangrove tersebut. 


\section{DAFTAR PUSTAKA}

[1] A. Isdianto ab et al., "Article history." [Online]. Available: http://jfmr.ub.ac.id

[2] D. Aliviyanti, A. Isdianto, A. M. Asadi, K. D. Saputra, D. F. Kristanti, and F. M. Haykal, "Komposisi dan Kerapatan Mangrove Kawasan Konservasi Taman Wisata Perairan Gugusan Pulau-Pulau Momparang".

[3] J. Ilmu Kelautan et al., "Identification and Analysis of Potential Coastal Areas As Basis for Mapping Conservation Areas in the Coastal District of Banyuwangi, East Java".

[4] A. Kurniawan et al., "Isolation and Identification of cellulolytic bacteria from mangrove sediment in Bangka Island," in IOP Conference Series: Earth and Environmental Science, Apr. 2018, vol. 137, no. 1. doi: 10.1088/1755-1315/137/1/012070.

[5] N. P. Tarigan et al., "282 MANAGEMENT OF AQUATIC RESOURCES Website: http://ejournals1.undip.ac.id/index.php/maquares KELAYAKAN WISATA ALAM DI MAROON MANGROVE EDU PARK SEMARANG The Feasibility of Nature Tourism at Maroon Mangrove Edu Park Semarang," 2017. [Online]. Available: http://ejournal-s1.undip.ac.id/index.php/maquares

[6] R. Ramadani, Z. IIman Navia, and K. Kunci, "PENGEMBANGAN POTENSI EKOWISATA HUTAN MANGROVE DI DESA KUALA LANGSA KECAMATAN LANGSA BARAT KOTA LANGSA ACEH DEVELOPMENT OF THE MANGROVE FOREST POTENTIAL POTENTIAL IN KUALA LANGSA VILLAGE KECAMATAN LANGSA BARAT KOTA LANGSA ACEH," 2019.

[7] N. Sagala, I. Regina Pellokila, J. Pariwisata, and P. Negeri Kupang Jl Adisucipto Kampus PenfuiKupang NTT, "STRATEGI PENGEMBANGAN EKOWISATA HUTAN MANGROVE DI KAWASAN PANTAI OESAPA".

[8] M. E. M Simbolon et al., "STRATEGI PENGEMBANGAN POTENSI WISATAKAWASAN MANGROVE DI DESA DUKONG KECAMATAN SIMPANG PESAK KABUPATEN BELITUNG TIMUR," 2021.

[9] D. Gede Mahardana et al., "STRATEGI PENGEMBANGAN EKOWISATA MANGROVE DI PROVINSI BALI MANGROVE ECOWISATA DEVELOPMENT STRATEGY IN BALI PROVINCE." [Online]. Available: http://ejournal-balitbang.kkp.go.id/index.php/JSJ/index

[10] C. Puspitaningrum et al., "STRATEGI PENGEMBANGAN EKOWISATA MANGROVE DESA SRIMINOSARI LABUHAN MARINGGAI LAMPUNG TIMUR Oleh," Agustus 2021 Fisheries of Wallacea Journal, vol. 2, no. 2, p. 2021. 
[11] M. Sabir Jurusan Administrasi Hotel and S. Tinggi Pariwisata Tamalatea Jl Perintis Kemerdekaan Km, "STRATEGI PENGEMBANGAN EKOWISATA MANGROVE TONGKE-TONGKE Di KABUPATEN SINJAI," 2020.

[12] A. Arfan, R. Maru, S. Side, and A. Saputro, "STRATEGI PENGOLAAN KAWASAN HUTAN MANGROVE SEBAGAI KAWASAN HUTAN PRODUKSI DI KABUPATEN MAROS SULAWESI SELATAN, INDONESIA".

[13] P. Buah Mangrove menjadi Olahan Makanan et al., "Pemanfaatan Buah Mangrove menjadi Olahan Makanan/Minuman di Desa Jangkaran, Kulon Progo," 2021.

[14] I. Zuraida, A. Yuli, I. Kusumaningrum, and B. F. Pamungkas, "PEMANFAATAN BUAH MANGROVE SONNERATIA SP. SEBAGAI BAHAN BAKU SIRUP DI DESA TANI BARU KABUPATEN KUTAI KARTANEGARA," vol. 4, no. 5, 2020, doi: 10.31764/jmm.v4i5.2975.

[15] A. Abidin, "Strategi Pengembangan Kecamatan Tapen Kabupaten Bondowoso Berbasis Energi Minihidro". 